ORIGINAL ARTICLE

\title{
Community and Communion Radio: Listening to Evangelical Programmes in a Brazilian Favela
}

\author{
Andrea Medrado \\ Media School, Bournemouth University, Fern Barrow, Poole, BH12 5BB
}

\begin{abstract}
According to academics and regulators, Evangelical and community radio belong to different sectors. Yet, in the favela, the urban environment and set of airwaves were saturated with religious sounds and programmes. On the basis of an ethnographic study of community radio in the everyday life of a favela, this research indicates that the two are often one and the same as the community radio stations would frequently broadcast Evangelical programming. This article argues that rather than trying to discover community radio's functions a priori, it is more helpful do so organically, step by step. What emerges is that such functions are multiple — religious, commercial, political — and not necessarily perceived as being paradoxical by their listeners.
\end{abstract}

doi:10.1111/cccr.12018

This article examines the experience of listening to Evangelical programming on the radio stations of Pau da Lima, a favela located in Salvador, Brazil, or what I am referring to as the communion uses of radio. This relates to Sconce's (2000) observation that, by functioning as a channel to connect listeners to other listeners and to other "incredible worlds," radio has an extra sensorial dimension which should not be ignored. Even if they were not necessarily religious, listeners perceived the act of tuning in to Evangelical programming on community radio as an act of welcoming messages for the greater good, which could offer them a sense of comfort in the hardships of everyday life in the favela. Yet, such uses of radio could also be understood as a problematic experience for the favelas as they often come into conflict with what is traditionally understood as community radio. Thus, my aim is to analyze some of the instances in which communion and community uses of radio both coincide and clash in the favela. Arriving in Pau da Lima to research community radio stations, I immediately noted the strong presence of religion whenever I tried to search for the FM community radio signals: I would catch a song, the voice of a pastor

Corresponding author: Andrea Medrado; e-mail: amedrado@bournemouth.ac.uk and ammedrado@hotmail.com 
preaching, or the jingle of an unknown Evangelical station. This article explores such links between FM community radio with the Evangelical churches (and radio) in Pau da Lima. It discusses how frequently Evangelical and community radios were one and the same, broadcasting Evangelical programmes or with the local stations simply becoming "pan-Evangelical.” In addition, it analyses the listening experiences of people who tuned in to Evangelical programmes and who were not all necessarily church members. Why did people listen to Evangelical programmes on community radio? How did listening to these programmes make them feel? In order to tackle these questions, this article draws on ethnographic observations of the experience of listening to Evangelical programmes in Pau da Lima. ${ }^{1}$ The research indicates that listening to these programmes was perceived as offering listeners an outlet for voicing their problems. These stations also often acted as councilors for everyday matters, such as fighting for one's rights as a citizen and so on. Additionally, as mentioned earlier, Evangelical radio and music were referred to as serving as "channels to God" for some listeners. At the same time, the fact that many Evangelical churches prevented their members from listening to secular music motivated members to actually leave such churches. On the one hand, Evangelical radio seemed to work precisely because it incorporated several principles of community radio, such as listening carefully to people who are used to not being heard. On the other hand, listening to Evangelical programming was described as "mind-limiting" because listeners were often told to "accept their fate," even if that meant attributing their poverty to God's will. This idea drastically contradicts many of the core values that revolve around community media and particularly those that perceive community media as agents of social change.

Religion has been largely regarded as a privatized matter in media studies. Meyer and Moors, for instance, note that the emergence of a Habermasian public sphere is dependent upon a decline in religion. In societies in which religion does play a noticeable role, this is interpreted as an indication of backwardness (Meyer \& Moors, 2006, p. 5). Within the field of community media studies, this lack of attention to religion is even more evident, particularly in Anglo-American literature. Being associated with sentimentality and illogic, religion is placed in direct opposition to the attainment of scientific knowledge (Boudewijnse, Droogers, \& Kamsteeg, 1998).

Within studies of community radio, the general attitude is to see religion with skepticism: If traces of religious broadcasting can be found in a particular radio station, then the tendency is not to place such station under the category of community radio. This is partly because all the actors and institutions involved in the making of community media, such as academics, activists, associations, and churches have long debated about what truly does and does not constitute "community media." This is epitomized by the World Association of Community Radio Broadcasters' (AMARC) attempts to find a definition that is able to encompass the very wide range of community media initiatives that exist in the world. The problem starts by attempting to define "community" in itself. Indeed, presenting a comprehensive definition of the term is beyond the aims of this article. Yet, there are three relevant points that need to be made here. Firstly, the notion of community is often identified 
with a relatively limited geographical region such as a neighborhood, village, or city (Jankowski, 2002). This works well in Pau da Lima's case since it is neatly circumscribed within geographical boundaries. "Community" might also refer to a "community of interest," where members have cultural, social, or political interests in common (Jankowski, 2002). However, as noted by Anthony Cohen, we must not forget that communities can also represent expressions of "difference." This means that communities are situated in symbolically constructed boundaries of symbolic practices (such as language, dress, customs, and rituals) that both "contain" and "differentiate" (Cohen, 1985, as cited in Howley, 2005, p. 5).

Explaining what one means by "community media" is an equally challenging task given the multitude of locally produced media initiatives, often of a small-scale and transitory nature, that exist all over the world. The general tendency, thus, is to define community media in terms of what they are not rather than on what they are: they are noncommercial, not owned by the state and, importantly, nonreligious. This definitional dilemma has ignited intensive debate and many scholars in the field now recognize the need to search for a more nuanced approach. Rodriguez (2001) points out that the term "alternative," which is frequently used, implies that alternative media have to be alternative to something. "This definition will easily entrap us into binary thinking: mainstream media and their alternative, that is, alternative media." Thus, this label limits the potential of these media to "resisting the alienating power of the mainstream" and blinds us from the other instances of change and transformation (Rodriguez, 2001, p. 33).

Carpentier, Lie, and Servaes (2003) incorporate Deleuze and Guattari's (2004) metaphor of the "rhizome" into civil society theory and put forward the label "rhizomatic media." More helpful than the proposition of yet another label is the authors' argument that the linkages between "alternative," "commercial," and "public service" media are far more multifaceted than the literature suggests. They then draw an analogy between these complex relationships and a "rhizomatic," rather than an "arbolic" way of thinking. While the arbolic is "linear," "hierarchical" and "tree-like," the rhizome is "non-linear, anarchic and nomadic," "connecting any point to any other point" (Deleuze \& Guattari, 2004, as cited in Carpentier et al., 2003, p. 61). Simply put, what concerns me here is the realization that community media tend to cut across borders between "commercial" and "public service" media. As I argued earlier on, my research demonstrates that this also applies to Evangelical and community radio in Pau da Lima. If one interprets the community media literature strictly, one would be led to disregard some of these local radio stations and programming as being merely religious and, consequently, not legitimate examples of community media. Yet, by adopting this simplistic approach, it is easy to miss the ways in which the radio being produced by favela residents is often deeply communal, even if the presence of Evangelical programming and the influence exerted by the churches over these stations contradict some of the core principles of community media (Girard, 1992).

The exclusion of the religious dimensions of community media is ironic, particularly if we consider the work of Brazilian Educator Paulo Freire. The author has 
served as a major source of inspiration for community media theory (Lewis \& Jones, 2006) and has helped create "a core philosophy within which to think through the nature of the active producer/active audience relationship" (Downing, Ford, Gil, \& Stein, 2001, p. 30). Freire was also known for embracing the Liberation Theology, a form of Christian socialism which emphasizes the Christian mission to bring justice to the oppressed through social and political activism. In this way, Freire felt that his Christian beliefs did not stand in opposition to his Marxist political activism. Indeed, he did not accept that there was such a dichotomy between his faith and his willingness to change very worldly matters, such as poverty, oppression and injustice. Freire poured his "almost biblical fervor" (Lewis \& Jones, 2006, p. 20), into his work and helped develop important concepts for grassroots media, such as empowerment, conscience raising (conscientização), and dialogical education. These ideas were incorporated into community media studies by contesting the dichotomy between "producers" and "audiences."

The Liberation Theology was also paramount in strengthening the community media movement in Brazil in the 1970s. It created a model of church practice through base communities (comunidades eclesiais de base), which consisted of small gatherings in which members could discuss issues related to their conditions of spiritual, economic, and social oppression. According to Festa and Lins da Silva (1986), these base community meetings often functioned as "spoken newspapers," in which people could discuss their daily struggles and learn about the importance of popular culture (as of culture "of the people") as a tool to express what it means to be "oppressed." This gave rise to popular communication movements and trade unions, contributing to the emergence of workers' bulletins, popular news agencies, and community radio (1986). These could be considered as predecessors of community media. Thus, in Brazil, community and religion were intertwined at the roots of the community media movement, particularly during the 1970s military dictatorship.

One problematic aspect in community and alternative media studies is that they tend to approach their object in a normative manner, usually associated with the political sympathies or antipathies of their authors. As a consequence, some dimensions of the phenomenon are either overestimated or overlooked. On one hand, there seems to be a significant interest in such stations' varying degrees of social activism. At the same time, the religious dimensions of community radio are often neglected, as I argue in this article. Thus, my aim here is not to define these functions a priori, but rather to discover them step by step. As a result, it emerges that these functions are multiple - religious, commercial, political, even personal — and, importantly, they are often not perceived by the listeners in Pau da Lima as being contradictory.

What follows in this article is a brief analysis of the establishment of Evangelical and community radio in the favela as well as of the ways in which the two are intertwined. In doing so, I hope to explore the community's different uses of Evangelical radio and to demonstrate that, in many instances, these uses are in line with both the notion of religious communion and community media. Nevertheless, there are tensions 
between community and communion radio. Here, it is worth clarifying that by "community media," I mean the local forms of media and, specifically, radio that are not only aimed but also produced by residents of the favela. The research focuses on solely one favela: Pau da Lima. This is consistent with the ethnographic approach adopted, which tends to favor depth over breadth. The fieldwork consisted of an immersion in the everyday lives of residents for 4 months ${ }^{2}$ plus a follow-up stay of one month. ${ }^{3}$ This included regular weekly visits to 10 selected families (once a week with each family), participant observations on the streets and in the homes and in-depth interviews with local radio producers and neighborhood association leaders. ${ }^{4}$

In order to examine the uses of community and communion radio, I draw on the experiences of my participant observations, delving into the ways in which community listening practices appropriate Evangelical radio and vice versa. I also wish to discuss the ways in which the Evangelical churches establish their presence in the favela's auditory space through the use of amplified sound and religious radio programming. In this way, it will be possible to gain an understanding of both the powerful appeal of Evangelical radios and the role of Evangelical radio in community media practice.

\section{Evangelical and community radio}

In Brazil, the term "Evangelical" often appears coupled with the term "media" but it is not always easy to define what different authors mean by it. Freston (1993) tends to use the terms "Protestants" and "Evangelicals" interchangeably but he notes that the vast majority of these churches in Brazil would be called "Protestants" in the Anglophone sense (2001). The author explains that the Protestants can be divided into Historical Denominations ${ }^{5}$ and Pentecostals. ${ }^{6}$ According to Freston (1993), there were three waves of Pentecostalism in Brazil that happened in the 1910s, in the 1950s-early 1960s, ${ }^{7}$ and in the late 1970-1980s. This last wave is often referred to as Neo-Pentecostalism, and its main representative is the Universal Church of the Kingdom of God (UCKG). ${ }^{8}$ In general, "Historical Churches attracted a membership higher in the social scale than the Pentecostals," and were more socially influential in the past. From Neo-Pentecostals or "believers" (crentes), the followers of the UCKG started to call themselves "Evangelicals," and today, this term is used indiscriminately by all groups.

There has been an extensive amount of debate on how the Evangelical churches have managed to attract large numbers of followers through their competent use of television and radio. Freston believes that the UCKG's "bold vision of penetration of cultural spaces" (2001, p. 15) resulted in a rapid growth in its membership numbers. ${ }^{9}$ One episode was crucial for the emergence of the UCKG as a major player in the profitable Brazilian media market-its purchase of TV Record in 1989. By 2005 TV Record managed to consolidate its position as the country's second largest TV network, second only to TV Globo. ${ }^{10}$ Today, the UCKG-owned Record Network 
includes television, radio (such as Rádio Record and Rádio Aleluia), newspapers, publishing houses, and recording studios (Rede Record, n.d., "jornais," "radio aleluia").

According to the Ministério das Comunicações (Ministry of Communications, n.d.), in 2009, there were 6,800 licensed FM stations in Brazil. ${ }^{11}$ The Ministry of Communications presents two general categories of FM stations: FM and community, and defines community FM radio stations as those that operate in low power, have a restricted coverage and whose licenses are awarded to not-for-profit community associations. Although this is not specified, it can be assumed that the vast majority of the noncommunity FM radio stations are privately owned. Interestingly, community radio dominates the radio scenario: 3,897 , or $57.3 \%$ of the 6,800 licensed stations, could be defined as community radio. Nevertheless, it is the commercial radio sector that is by far the strongest in the Brazilian radio industry, raising an average of US\$262 million annually in advertising revenue. ${ }^{12}$

There is not space here to deal with the methodological vagaries evident in these categorizations, such as the fact that religious motivations of radio broadcasters are not taken into account by the Ministry of Communications. However, even within this framework, it is possible to appreciate the dominance of Evangelical radio. Figueredo Filho's (2008) research shows that, in 2006, 25.18\% of the FM radio stations and $20.55 \%$ of the AM radio stations in Brazil's capital cities were owned by Evangelical churches. The most notable examples are the UCKG, with 24 FM radio stations, and the Assembly of God (AG), with nine AM stations. His study only focuses on the urban radio markets, having analyzed the presence of evangelical media in Brazil's state capitals. However, it does help provide a dimension of the considerable pervasiveness of Evangelical radio in the country.

According to the regulation, the larger Evangelical radio stations, such as the UCKG's Rádio Aleluia, fall under the umbrella of generic commercial FM radio ${ }^{13}$ and thus belong to a category that is distinct from community radio. However, Evangelical and community radio do share a number of features in common. Miranda Costa, Gomes de Souza, and Cardoso (2003) for instance, argue that the evangelical FM stations have a "participatory" nature and are smaller in scale, giving the listeners opportunities to make suggestions on the programming and tell their own personal stories (2003, p. 3). The other similarity has to do with the intended audiences of both community and Evangelical radio. The former's raison d'etre is to "give a voice to the voiceless" and to address the concerns of the underprivileged classes: precisely the demographic amongst which the Evangelical churches (and, consequently, Evangelical radio) thrive. Referring specifically to the UCKG, Reis points that the church is very successful in "targeting poor and disenfranchised urban populations"; "buying and expertly using media channels; and purchasing highly visible cultural landmarks, such as historic movie theatres and music venues" (2006, p. 178). In the Brazilian urban context, these economically and socially vulnerable populations often coincide with that of the favelas. Finally, as Figueredo Filho (2006) suggests, the considerable segmentation of Evangelical groups resonates with 
some of the debates within community media studies. Socially and economically underprivileged groups started their own form of "do-it-yourself" religion as a way to "rebel" against the authoritarian and hierarchical churches. This echoes some of community media's principles, such as offering an outlet for the oppressed to express themselves and actively take control of their own media representations in a world of powerful media institutions.

While there are significant points of intersection between community and Evangelical radio on a broader level, these linkages become ever more present and complex at the local grassroots level. During my fieldwork in Pau da Lima, I would frequently see houses with wide doors, which turned out to be Evangelical churches. Some were small and precarious while others were spacious and impressive looking. From the streets, one was able to see the inside of the churches with their wide and unfurnished spaces, filled mostly by white plastic chairs. During cult times, ${ }^{14}$ it was possible to see dozens of people inside, usually standing, sometimes with one of their arms stretched, and singing with their eyes closed as the songs mixed with the sounds of the street. The presence of the Evangelical religion was also noted when I tried to search for the FM community radio signals on a portable radio. I soon found out that there was a range of unlicensed community radio stations located in the neighboring areas. What was striking, however, is that of these stations, most had daily slots dedicated to Evangelical programmes. There were also many instances of radio stations owned by small local churches, which were thus entirely dedicated to broadcasting religious programmes. The intricate physical and spatial configuration of the favela, the transitory nature of the stations and the vast number of small churches spread across the hills made it challenging to obtain an accurate map of all the stations and their locations. But the overall impression was clear: of an urban environment and a set of airwaves saturated with religious sounds and programmes. It can be argued that the Evangelical churches are skilled radio makers and quite successful at appealing to their listeners. In the following sections, I wish to demonstrate the ways in which the Evangelical radio stations play a role which has been often attributed to community radio (for example, by giving a voice to certain groups in the community which were not being heard). While these uses might sometimes come into conflict with community radio principles, they are also in line with the communion offered by religion.

\section{Evangelical community radio in Pau da Lima}

Salvador is the third most populous city in Brazil with a population of over 2.5 million inhabitants (IBGE - Brazilian Institute of Geography and Statistics, 2010 Census, n.d., "população," "Salvador"). Pau da Lima represents one of the city's 18 "Administrative Regions" or districts. With a population of approximately 120,000 residents, it is considered the third most populated district in Salvador. Although it is located in what is known as the city's central core (miolo central) Pau da Lima is considered a "peripheral" neighborhood for socioeconomic reasons. The district is 
distant from the city's coastlines and tourists' preferred spots, lacks infrastructure and has several impoverished "invasion" areas.

There is a significant body of scholarship on favelas that demonstrates that these are not homogenous environments (De Medina, 1964; De Queiroz Ribeiro \& Correa do Lago, 2001; Perlman, 1976). Indeed, the residents of Pau da Lima are not necessarily all poor. Some people are employed in the formal sector and others are self-employed or own small businesses. However, a significant amount of the population is employed in low-paying occupations, such as construction work and domestic services. According to the IBGE 2000 census, 70\% of the neighborhood's households earn three minimum wages ${ }^{15}$ or less. Generally, therefore, it is extremely difficult to make ends meet.

At the time of research, ${ }^{16}$ there were four unlicensed community radio stations consistently operating in the Pau da Lima surroundings. These were Axé FM, Planeta FM, Ouro FM, and Panorama FM. All these stations evidenced linkages between Evangelical and community radio, falling into two broad categories: (a) Those which were not owned by Evangelical churches such as Axé FM, Planeta FM, and Ouro FM and that contained a mixture of secular and Evangelical programming; (b) Those that defined themselves as "pan-Evangelical," such as Panorama FM, which aired purely Evangelical material, although the station did not belong to a particular Evangelical subdenomination.

In terms of content, three stations-Axé FM, Planeta FM, and Ouro FM-were music stations and used a similar format for their religious programming, but each focused on a different secular music genre. For example, as the name suggests, Axé FM was known for playing mostly Axé music, a popular genre originated in Salvador, which is influenced by Afro-Brazilian music and is associated with the carnival celebrations. ${ }^{17}$ Planeta FM was more eclectic and played reggae, hip hop, rap, pop, R\&B (Brazilian and international). As a general rule, if compared to Axé FM, some of the genres played by Planeta FM, such as reggae, hip hop and rap, were more politically and socially engaged. As for Ouro FM, the station targeted an older audience by playing mostly Brazilian genres such as seresta and sertanejo. ${ }^{18}$ However, each one of these three stations also dedicated three daily slots for Evangelical programming at peak listening hours - at 7 a.m., 12 p.m., and 6 p.m. Each one of three slots had as its presenter a pastor or preacher from a local Evangelical church. The programmes could be described as Evangelical in the broad sense of the term as they did not necessarily make reference to a particular historical or Pentecostal church. The content of such programmes could be described as a combination of preaching, phone-ins by listeners asking for advice on various everyday and spiritual matters and gospel music. Although it was also a music station, Panorama FM was different in that it played religious music only. The music consisted of either gospel or popular genres, such as pop, rock, or even Brazilian rhythms, such as forró and samba, adapted in order to have religious lyrics. The station also had various presenters who appealed to different Evangelical subdenominations by preaching or offering counseling on spiritual and daily issues. 
What I seek to argue here is that community radio in the favela has to operate within an environment that is highly compromised by various interests other than serving the public in a local community (and indeed different versions of serving the local community). Thus, community radio needs to be understood more clearly as operating not in a separate realm but one thoroughly constrained by — contaminated by, one might say - a mixture of politics, commercialism, and religion. Although the first two elements should not be ignored it is the latter that concerns me here. The connections between community and Evangelical radio were explained to me by Paulinho FP, the founder of the Association of Community Radio Professionals ${ }^{19}$ in Bahia and director of a station called Copacabana Comunitária. ${ }^{20}$ He stated that many of the community stations tended to mix secular and religious music and programming. This also applied to Copacabana Comunitária, which had 3 hours of Evangelical programming:

When we started with these programmes, people would say: these believers, they are no good. But I would say: don't say that . . you have 7 hours of secular music here. The brothers, they are speaking about Jesus . . . it's good for our neighbourhood. The presenters are usually pastors. When they can't come they send someone who is well prepared and knowledgeable about the scripture.

(Paulinho F. P., Founder of the Association of Community Radio Professionals $)^{21}$

In my research, community radio practitioners such as Paulinho tended to use the following arguments to justify the presence of Evangelical programmes in their radio stations: First, the station needed to appeal to the different groups of the community. As a numerically significant group, the Evangelicals could not be ignored. Second, the messages of religious programmes tended to be positive, focusing on peace, "speaking of Jesus Christ" and thus were welcomed by people who experience a lot of violence in their daily lives. Finally, they argued that the stations needed to be plural, offering a space for the different religions that exist in Pau da Lima. In reality, often one does not find such plurality on the stations' programming as the Evangelicals seemed to have much more space on air than other religious groups. ${ }^{22}$ The radio practitioners justified this by saying that this was simply because the Evangelicals have more initiative, seeking the stations more. Indeed, as I will demonstrate later in this article, many of the listeners that I observed in Pau da Lima, had a tendency to attribute generic positive connotations to religious programming, even if they were not necessarily religious. For example, one resident of Pau da Lima, Regina, who had decided to leave the AG after being a church member for 10 years, was generally skeptical towards religion. At the same time, she would often say that "any music that speaks of Jesus can't be a bad thing in the context of the favelas" (Fieldnotes, December 08, 2007). However, the prevalence of Evangelical programming on air also meant that nonreligious community organizations resented their lack of access to these stations. During one of my visits to the Residents of Pau da Lima Neighbourhood Association, AMPLI, ${ }^{23}$ for instance, Wellington, a 
community leader, told me that many opportunities were being wasted by Pau da Lima's community radios. According to him, they established good dialogs with some groups, such as the churches, but neglected others, such as the Association itself. "It could be really useful for AMPLI to use the radio to announce our events, our elections, but it's not like we have completely open access to the stations. Planeta FM, for example, is located near us, but I don't always feel like I can knock on their door" (Fieldnotes, December 8, 2007). Therefore, the radio stations' premise that the Evangelicals are the only religious group who seek space in the neighborhood radio obscures a much more complex picture. ${ }^{24}$ In one of my visits to a Regina, ${ }^{25}$ I arrived when the Reborn in Christ Church's cult was taking place in the neighborhood. The church's sounds, amplified by loudspeakers, resonated on the hills. The singing and shouting of the pastors and cult goers echoed the strength of the Evangelicals as a legitimate social group on the hills, affirming that they deserved attention. The blatant presence of religious programming on the airwaves of Pau da Lima demonstrates a similar strategy of using the radio as tool for the Evangelical religious groups to establish their presence in the neighborhood.

A few academic works on alternative media have stressed the sometimes contradictory relationship between their anticapitalist rhetoric and their concrete practices of commercialism (Atton, 2002). Similarly, in Pau da Lima, there was a business dimension to the connections between Evangelical and community radio. These local radio stations would sell slots to the local Evangelical churches or to religious presenters themselves. ${ }^{26}$ They were expected to pay a fee for the slot, but could keep $50 \%$ of the advertising revenue. ${ }^{27}$ Once pastor-presenters had managed to attract a fairly loyal listenership, they could seek "sponsorships" from local shop owners in exchange for announcements about their events or products. Words like "sponsorships," rather than "adverts," were used as a way to avoid the station being perceived as commercial. In practice, however, this can be understood as another dimension to entrepreneurship. Thus, the Evangelical programmes can be seen as constituting another aspect of the "making a living" ethos of the favelas. Paradoxically, it appears that this religious nature is in itself inflected with commercialism.

During one of my visits to Edu, a 20-year old resident of an impoverished area of Pau da Lima called Pistão, I heard the programming of Panorama FM, an unlicensed station which called itself "pan-evangelical."

Panorama FM 97.9. Denominations without barriers. Assemblies, Baptists, Reborn, God is Love, Winners in Christ, Pentecostals. The choice is yours. Join our kingdom. (Transcribed from the radio in Edu's house during a visit,

December 01, 2007)

This resonates some of Figueredo Filho's (2006) claims that radio broadcasting might be playing a role in bridging the differences between different Evangelical groups. Given the impressive rise of the Neo-Pentecostals and the large numbers of small churches which flourish daily, these local radio stations seem to be making 
a deliberate attempt to attract listeners from various churches and even nonEvangelicals. Additionally, Panorama FM epitomizes the intimately linked but paradoxical relationship between community radio, commercial radio and religious radio. While it was predominantly known for its religious programming, the station frequently played the role of community radio, for example, by taking part in local charity campaigns. At the same time, its pan-Evangelical orientation was also a commercial strategy, broadening the station's listenership to include not only the religious residents but also people who were fans of feel-good music but not necessarily religious such as Edu, as I will discuss in the next section.

\section{Listening to Evangelical programming in Pau da Lima: Belonging, not-belonging, counseling, community, and communion uses of radio}

The communion uses of radio in Pau da Lima manifested whenever the act of tuning in to an Evangelical radio station became "an important means to be in touch with God” for listeners (Oosterbaan, 2008, p. 126). Sconce (2000, p. 3) also explores this phenomenon of communion being facilitated through broadcast media by pointing out that media often have the power of an "animated living presence." The author notes that "in the age of telegraphy and wireless, many believed that telegraphs could be used to contact incredible worlds, be them extrasensory or extraterrestrial" (Sconce, 2000, p. 10). Radio, in particular, has an "ethereal presence of communication without bodies" (Sconce, 2000).

Some of these ideas manifested in the daily listening of Dona Joana and Seu Carlitos. The couple belonged to the Seventh Day Adventist Church. Dona Joana had a very active role in the church. She woke up every day at 5 a.m. to "study the bible" and then she switched on the radio to listen to Radio Novo Tempo's "28 "It Is Time for Prayer" ${ }^{29}$ programme.

People can phone in, send prayer requests. Someone is going to have a serious surgery. The presenter reads the request and invites all the listeners to pray for that person. The stories draw you in. You're praying for other people, together with other people. (Dona Joana, primary school teacher, resident of Pau da Lima, personal communication, November 20, 2007).

Dona Joana's use of the radio, as it was the case with other residents in the favela, displayed a belief in the radio as a form of channel of holiness: the radio was absorbing all the listeners' prayers and sending them to the person who requested them, simultaneously offering a form of communion and a sense of community. Through the competent oral performance and storytelling of the pastor, Dona Joana felt closer to God and ready to start the day. Besides experiencing the presence of God through the prayers of the presenter, she could also experience the presence of other "brothers in Christ," the community, as all of them joined a chain of prayer.

Additionally, there was an important affective dimension to radio listening in Pau da Lima. This becomes evident if we attend to the relationship between belief and music in the favela. Edu's listening practices exemplified the ways in which 
community listening practices appropriated Evangelical radio: He was a loyal listener to Panorama FM, Pau da Lima's "pan-Evangelical" radio. However, he was not Evangelical himself. Ironically, he was a pagode dancer, a rhythm that was often referred to as "sinful." In the Rio de Janeiro favelas, Oosterbaan observed that while gospel music was associated with God, funk music was associated with drugs, sex, and the devil (2008, p. 82). In Salvador, pagode replaced funk as the rhythm that was played at parties while the sensuous dancing style was perceived as immoral. Nevertheless, being a professional pagode dancer did not prevent Edu from being an enthusiastic fan of gospel music.

I really enjoy the accolade music. It is so peaceful, it makes me feel good. The fact that we're not going to church doesn't mean that we're not God fearing. These kinds of songs are always good for you, they warm up our heart. (Edu, resident of Pau da Lima, dancer, personal communication, December 1, 2007).

For Edu, listening to Evangelical programmes on a local unlicensed radio station was not at all dependent on his church going habits. This perhaps is an example of a more universal theme noted of "believing without belonging" (Davie, 1994). She argues that religious broadcasting seems to "permit, encourage, even, a rather self-indulgent form of armchair religiosity" (Davie, 1994). This idea can be applied to the religious listening habits of Edu. By "warming up his heart" the programmes seem to be providing him with comfort and pleasure rather than facilitating his affiliation to the nearest church.

Edu also spoke of the Evangelical songs as if they were a form of remedy with which to combat the stress and unease of everyday life. This echoes some of De Nora's (2000) notions of music playing a role of "care of self." She finds that the "rhythms, harmonies, and styles" of music are used to guide listeners to "where they wish to be or go, emotionally, physically and so on" (De Nora, 2000). Therefore, the listeners in Pau da Lima seemed to be aware of music's intrinsic mood generating qualities and would deliberately use Evangelical music according to their emotional states and needs.

Yet, Edu's listening habits were also influenced by his personal connections in Pau da Lima, almost as much as by his music taste. Besides having Panorama FM on the background, he would often listen to Axé FM, another unlicensed community radio station in Pau da Lima, mostly on "Saturday mornings and Sunday afternoons." When asked what he enjoyed about the radio station, he identified "the type of music" as one of his reasons. However, Edu would also tune in to Axé FM to listen to a programme presented by one of his friends, Geovane, which played axé music and pagode and was on air on Saturdays at 10 a.m. He enjoyed listening to his friend on air and would often request songs when meeting him in person around the streets of Pau da Lima. He described one instance in which Geovane invited him to the studio:

When you hear the radio shows, they often play sound effects, people cheering, so, when I went to the studio with Geovane, I was really surprised to see that he was confined in that little room all by himself. Whenever I get a chance, I let him know that I listen to his programme because if I were in his situation it would 
make me happy to know that someone out there is listening. (Edu, personal communication, December 8, 2007).

Knowing his appreciation of gospel music, I asked him if he listened to any of the Evangelical shows broadcast by Axé FM. His response was negative: Edu did not identify himself as a "loyal listener" of the station. His listening to Geovane's show on Axé FM was motivated by personal loyalty rather than by his religiosity or even by his music preferences (Edu, personal communication, December 8, 2007).

There were also instances in which the inter-mingling of religious and community radio was not positive, especially when the commercial imperatives of sponsorship discussed earlier are taken into account. One day, Regina, whose family I was frequently visiting, took me to see her sister Rita who lived in an impoverished area of Pau da Lima. As soon as we entered her house, Rita picked up a piece of paper and waved it to Regina:

Rita: "It's the phone bill. 100 Reais."

Regina: "How come? Who are you calling?"

Rita: "The pastor in a radio station." (Rita, unemployed, resident of Pau da Lima; Regina, field researcher at Fundação Fio Cruz, resident of Pau da Lima, personal communication, December 14, 2007)

Rita then started to tell us a somewhat tragic-comic story about her ringing of a pastor on air:

One day I picked up the phone and told the pastor that I was drunk. I thought he was going to hang up on me, but he didn't. He told me that Jesus loved me, that I was not alone in my problems. So, I started to call every night. He invited me to church but I never set foot there. I spent like a month calling him many times, drunk. The pastor would tell me that drinking was a sin, but there was still salvation. But then, one day, I think he realised that I wasn't going to stop drinking so he stopped answering my calls. Now I'm stuck with the phone bill. (Rita, unemployed, resident of Pau da Lima, personal communication,

December 14, 2007)

Rita's story sounded like that of a person craving to be heard and to find some solutions for her various problems in life. When she tuned in to the station, she found someone who was willing to listen to her (for a while). This relates to the potentially therapeutic properties of radio. Hendy (2000) has shown how the medium can be particularly suitable for intimacy. Given the blindness of radio, in the privacy of their homes, listeners might feel more prone to open up to the presenters (and other listeners). It is reasonable to suggest that the Evangelical programme represented a type of mediated therapist's couch for Rita. Nevertheless, this idea of the "talking cure" being achieved via radio brings other problems. Cameron (2000, p. 157) discusses the ways in which a recurring cliché is that one must not keep feelings inside oneself. The author adds that whenever an individual "fails to represent what is inside 
intelligibly," this is considered a communication problem (Cameron, 2000, p. 159). Therefore, Cameron questions this widespread usage of "talking cure." The objects are people who are merely trying to confront serious problems which, however, "have little to do with the way they talk and are unlikely to be cured by a dose of communication training" (Cameron, 2000, p. 175).

Furthermore, in Rita's case, the Evangelical programme on community radio allowed for a sense of communion with God-a greater "healing force" as she found out that "Jesus loved her"; communion with other listeners - who were praying for her and through her storytelling on air got spiritually connected to her struggles - as well as community - as she realized that "she was not alone in her problems." However, while talking on air was initially enjoyable for Rita, it is questionable that it was beneficial for her in the long term. Rita's personal history and problems were too complex to be fully understood and dealt with through a few minutes of on air interaction with the pastor. In the end, Rita ceased to be radio novelty. Therefore, here we had a clear example of how Rita's use of Evangelical radio has eventually come into conflict with community radio principles. Her immediate emotional relief achieved through a superficial "talking cure" and the pastor's temporary companionship gave way to the frustration of being left with an expensive phone bill. The fact that the radio provided her with a voice was not aimed at triggering a sustained change in her life for the better but, rather, it seemed like an opportunistic trick to keep her tuned in. Ultimately, the pastor's willingness to have Rita on air night after night was consistent with the commercial imperatives of good radio: that is, compelling content that will keep listeners in the flow and attract sponsorship to his programme.

Regina's religious and listening experiences have been quite different from those of her sister. She had quit the Assembly of God at the time of research. However, she recognized that the church had an important role at a previous time in her life.

When I accepted Jesus, it was at a time that I was suffering a lot in my life. I got divorced. My daughter was only three. Their dad used to drink a lot. Seeing a family go to the church was the most beautiful thing in the world ... I saw my niece getting ready for church. I thought that she was happy. I didn't see what I see today ... that she is oppressed, that she suffers a lot with her husband too. The believers ... they think you have to carry your cross, it's the will of God ... (Regina, personal communication, May 20, 2009)

Regina attributed her conversion to her fragile emotional state at the time. Given the hardships of life in the favela, joining the church was the only guarantee that she could keep an alcoholic husband (and alcohol in general) away from her family and her life. The church represented the shortcut to achieve a happy and "clean" life. But, as well as supplying a network of support, the church also acted as a network of surveillance - pastors using all forms of what Regina called "psychological pressures" to tell people about what they should consume and not consume, including media:

I would go to the church and ask for forgiveness because I listened to a song that reminded me of my teenage years! They say that remembering the times when 
you were a part of "the world" is like eating your own vomit. When I left the church it was because of these things. They use a form of psychological torture. They claim to have revelations. You go there and the pastor says: you, the one who is ill ... Of course, there is always someone in the crowd who is going to be ill! Then they say: God is telling me that one of you is listening to music of the world ... people fall for the story. (Regina, personal communication, May 20, 2009)

Regina had been attracted to the church because she wanted to be drastically removed from a "corrupted" world that had caused her pain. However, it was this same drastic removal that ended up alienating her from the church. The simple pleasures of music, such as its ability to trigger memories of her teenage years could no longer be enjoyed. As Oosterbaan (2008) noted, Evangelical Christianity is permeated by the notion of sound and music as shortcuts for reaching God. For Regina, this worked differently. What put her off was the fact that she was missing things like books, music, and radio so much. In other words, just like listening to Evangelical stations could serve as a direct bridge to God, it also represented the disruption in the sought after road that takes one to God. In Regina's case the church's imposition that she remained alien to the "worldly" matters around her deeply contradicted some of the Freirean notion that, by raising their conscience, that is becoming aware of the harsh realities around them, people can change these realities and free themselves from oppression. Consequently, Regina's story provided an example in which listening (and not listening) to the radio might have provided some temporary communion but stood in stark opposition to ideals which are at the core of community radio.

I will now return to Dona Joana and Seu Carlitos, who were both devoted members of the Seventh Day Adventist Church, and, specifically, to Dona Joana's religious beliefs and listening habits:

I only like songs that praise the Lord. The other songs just don't enter in my heart. If I go somewhere and they are only playing music of the world I feel out of place. (Dona Joana, primary school teacher, resident of Pau da Lima, personal communication, October 6, 2007)

Dona Joana created a very clear-cut separation between the Evangelical songs and "the other songs"; the world where she belonged — the world of God — and the "worldly" world in which she felt out of place. Nevertheless, as I kept going back to their house every week, a much more complex scenario started to be unveiled. We would end up discussing racism, social inequality, violence, and politics, among many other topics. One of the reasons why Seu Carlitos and Dona Joana enjoyed listening to Radio Novo Tempo was because the station had several programmes which offered health tips and advice for social matters.

In their programmes they have a pastor, like a teacher. They talk about what to do if your child is not doing well at school ... They talk about how we should 
eat. They even have a doctor who answers questions to do with women's health.

(Dona Joana, personal communication, October 27, 2007)

Thus, one should still try to resist thinking of Evangelicals and Evangelical music in an overly deterministic way. It became evident that Evangelical religiosity did not necessarily imply political apathy and that "warming up the heart" with Evangelical songs would not always mean having a stiff cold reaction to secular music.

\section{Conclusion}

This article demonstrates that adopting a normative approach to community media studies, and, as a consequence, disregarding the place of religion in community media, is unhelpful. Adopting an ethnographic perspective, the boundaries that separate Evangelical and community radio in Pau da Lima become significantly blurred. Indeed, community listening practices would often appropriate Evangelical listening practices and vice versa. Community radio often draws on the strong senses of communion and belonging offered by religion. This manifested, for example, in Dona Joana's use of radio as a shortcut for reaching God and connecting to a network of support. In this instance, the communal and the community, in its most traditional sense of sharing common beliefs, happened to coincide. Further, community radio skillfully made use of Evangelical songs and religious positive messages. These were used by listeners such as Edu to "warm up their hearts" in a form of "armchair religiosity" (Davie, 1994) which enabled them to believe, on their own terms, without necessarily belonging to any church. At the same time, Evangelical radio seemed to thrive in the favela precisely because it would often take on board some of the traits which are traditionally associated with community radio. Yet, as Rita's experience of being abruptly cut off by a pastor who decided she was no longer good radio demonstrates, there is no evidence that Evangelical programming on Pau da Lima's community radios might be acting as a catalyst for social change. Indeed, even some religious listeners, such as Dona Joana and Seu Carlitos, resented the fact that the radio stations did not engage with political and social matters more directly. At the same time, one cannot deny that Evangelical and community radio do share some significant similarities such as successfully addressing the marginalized classes and representing a form of do-it-yourself media.

When embracing an immersive ethnographic approach, one is faced with a scenario permeated by imperfections and a reality that cannot be easily interpreted. This applies to the favela itself, where one can find poverty, violence, and injustice but also creativity, entrepreneurship and prosperity. Likewise, this was the case with Evangelical (and, on) community radio in the favela, which served as an important tool for self expression but which, at the same time, was not flawless, privileging the interests of some groups over others. My research has indicated that the linkages between community radio and Evangelical radio could be found in ways which were unusual, contradictory, less than community orientated. While they sometimes played a role in giving a "voice to the voiceless," they could also be individualist, 
commercial, and even rhetorically manipulative in many instances. What I suggest is that the sector is richer, more complex and nuanced than we have tended to assume in the rhetoric of academic and campaigning discourses surrounding community media. On the one hand, the Evangelical programming could not be described as politically or socially radical. On the other hand, converting to Evangelical churches is often associated with a sense of attainable economic prosperity (Birman, 2006) and, as a consequence, tangible social change, for many families in impoverished communities such as the favelas. Similarly, listening to Evangelical programmes on community radio could be perceived as enhancing the residents' sense of belonging and as being linked to their self-improvement. Yet, it could also be associated, as it was the case with Regina, with shying away from critical thinking or in Freire's (1972) terms, "raising one's own conscience." In any case, this is how Evangelical radio in the favela works: You might not believe it, but you will certainly hear it.

\section{Notes}

1 The research methodology draws on media ethnography. Weekly family visits and participant observations were conducted in the homes and on the streets of Pau da Lima from September 2007 to January 2008 plus a follow-up visit of further full month in May 2009.

2 In 2007-2008.

3 In 2009.

4 In addition, I also taught a creative writing course for a group of young students during my first stay in Pau da Lima in exchange for the community's collaboration for the research project.

5 Among historical churches are the Lutherans, Presbyterians, and Baptists.

6 Among Pentecostals are the Christian Congregation and the Assemblies of God.

7 Three large groups were formed (among dozen of smaller ones): The Church of the Four-Square Gospel (1951), Brazil for Christ (1955), and God is Love (1962). All began in São Paulo (Freston, 2001).

8 In Portuguese: Igreja Universal do Reino de Deus, also known by its acronym IURD.

9 According to an article published by one of the country's most known newsmagazines, "Revista Veja," the UCKG's membership grew by $280 \%$ in Brazil in the first half of the 1990s, going from 900,000 to 3.5 million members in only 5 years (as cited in Reis, 2006).

10 In 1997, for instance, TV Record established its own division for television drama, starting to produce telenovelas (soap operas) and stepping into an area that had traditionally been dominated by TV Globo.

11 The number of AM radio stations is smaller, with a total of 1,913 stations in the country in 2009.

12 Anuário de Mídia (Media Annual Report), Grupo de Mídia. Television, however, has the much greater advertising revenue of more than 3 billion US dollars.

13 In the commercial radio sector, evangelical radio stations also have a strong presence with over $25 \%$ of the FM radio stations in Brazil's capital cities being owned by Evangelical and mainly Pentecostal churches in 2006.

14 Usually in the evening around 6 p.m. and 7 p.m. 
15 As of March 01, 2011, the minimum wage is 545 Reais.

16 Between October 2007 and January 2008.

17 The term "axé" originates from the Yoruba language and from greetings used in the Candomblé and Umbanda. It means "good spirit" or "good vibration." Artists such as Luiz Caldas and Ivete Sangalo are known for singing "Axé Music."

18 Seresta comes from a bohemian tradition of romantic songs, while sertanejo can be broadly described as the music which originates from the country side.

19 In Portuguese, APRACOM.

20 Located in the neighbourhood of Cosme de Farias.

21 Interview on December 10, 2007. His real name.

22 Another issue that deserves to be mentioned is that of the religious intolerance by some of the Evangelical groups in relation to commonly practiced Afro-Brazilian religion of Candomblé. However, unfortunately, there is no space to delve into this issue here.

23 Associação dos Moradores do Pau da Lima, known by its acronym AMPLI.

24 Antonio Pierucci (2006), for instance, distinguishes between "religions of conversion" and religions of "ethno-cultural heritage" such as Candomblé.

25 The use of radio as a tool for conversion is not an integral part of the latter.

26 All residents of Pau da Lima were assigned fictitious names to protect their anonymities.

27 This also frequently happens with national television broadcasters, such as Rede Bandeirantes (De Lima, 2008).

$2850 \%$ goes to the station.

29 Adventist AM radio station.

30 É Tempo de Oração in Portuguese.

\section{References}

Atton, C. (2002). Alternative media. London, England: SAGE.

Birman, P. (2006). Future in the mirror: Media, evangelicals and politics in Rio de Janeiro. In B. Meyers \& A. Moors (Eds.), Religion, media and the public sphere (pp. 52-69). Bloomington: Indiana University Press.

Boudewijnse, B., Droogers, A., \& Kamsteeg, F. (1998). More than opium: An anthropological approach to Latin American and Caribbean pentecostal praxis. Lanham, MD: Scarecrow Press.

Cameron, D. (2000). Good to talk? Living and working in a communication culture. London, England: SAGE.

Carpentier, N., Lie, R., \& Servaes, J. (2003). Community media: Muting the democratic media discourse? Continuum, 17(1), 51-68. doi: 10.1080/1030431022000049010.

Cohen, A. (1985). The symbolic construction of community. Cambridge, MA: Tavistock.

Davie, G. (1994). Religion in Britain since 1945: Believing without belonging. Oxford, England: Blackwell.

De Medina, C. A. (1964). A Favela e o demagogo. São Paulo, Brazil: Leituras de Povo $n^{\circ} 3$.

De Nora, T. (2000). Music in everyday life. Cambridge, MA: Cambridge University Press.

De Queiroz Ribeiro, L. C., \& Correa do Lago, L. (2001). A oposição favela-bairro no espaço social do Rio de Janeiro. São Paulo em Perspectiva, 15(1), 144-154, 200.

Deleuze, G., \& Guattari, F. (2004). A thousand plateaus: Capitalism and schizophrenia. London, England: Continuum. 
Downing, J. D. H., Ford, T. V., Gil, G., \& Stein, L. (2001). Radical media: Rebellious communication and social movements. Thousand Oaks, CA: SAGE.

Festa, R. D., \& Lins da Silva, C. E. (1986). Comunicação popular e alternativa no Brasil. São Paulo, Brazil: Paulinas.

Figueredo Filho, V. (2006). Liturgia da espiritualidade popular evangélica brasileira. Rio de Janeiro, Brazil: Publit.

Figueredo Filho, V. (2008). Os três poderes das redes de comunicação evangélicas: Simbólico, econômico e político. Ph.D. Thesis, Instituto Universitário de Pesquisas do Rio de Janeiro.

Freire, P. (1972). Pedagogy of the oppressed. New York, NY: Continuum.

Freston, P. (1993). Brother votes for brother: the new politics of protestantism in Brazil. In V. Garrard-Burnett \& D. Stoll (Eds.), Rethinking protestantism in Latin America. Philadelphia, PA: Temple University Press.

Freston, P. (2001). Evangelicals and politics in Africa, Asia and Latin America. Cambridge, MA: Cambridge University Press.

Girard, B. (1992). A passion for radio: Radio waves and community. Montreal, Canada: Black Rose Books.

Hendy, D. (2000). Radio in the global age. Malden, MA: Polity Press.

Howley, K. (2005). Community media: People, places and communication technologies. Cambridge, MA: Cambridge University Press.

Instituto Brasileiro de Geografia e Estatística (IBGE) (n.d.). Retrieved from http://www.censo2010.ibge.gov.br/primeiros_dados_divulgados/index.php?.uf=29

Jankowski, N. (2002). The conceptual contours of community media. In N. Jankowski \& O. Prehn (Eds.), Community media in the information age: Perspectives and prospects. Cresskill, NJ: Hampton Press.

Lewis, P., \& Jones, S. (2006). From the margins to the cutting edge: Community media and empowerment. Cresskill, NJ: Hampton Press.

Meyer, B., \& Moors, A. (2006). Religion, media and the public sphere. Bloomington: Indiana University Press.

Miranda Costa, L., Gomes de Souza, F., \& Cardoso, C. K. (2003). Em nome de Deus: as ondas radiofônicas louvam cada vez mais ao senhor. Presented at XXVI Congresso Brasileiro de Ciências da Comunicação INTERCOM (Sociedade Brasileira de Estudos Interdisciplinares da Comunicação) Belo Horizonte-2 a 6 Set.

Oosterbaan, M. (2008). Spiritual attunement: Pentecostal radio in the soundscape of a favela in Rio de Janeiro. Social Text, 26(3), 123-145. doi: 10.1215/01642472-2008-007.

Perlman, J. (1976). The myth of marginality: Urban poverty and politics in Rio de Janeiro. Berkeley: University of California Press.

Pierucci, A. (2006). Religião como solvente. Novos Estudos CEBRAP 75, 111-127. Retrieved from http://socialsciences.scielo.org/scielo.php?pid=S0101330020 06000200002\&script=sci_arttext

Rede Record (n.d.). Retrieved from http://rederecord.r7.com

Rodriguez, C. (2001). Fissures in the mediascape: An international study of citizens' media. Cresskill, NJ: Hampton Press.

Sconce, J. (2000). Haunted media: Electronic presence from telegraphy to television. Durham, NC: Duke University Press. 